\title{
Assets need audiences: How venture capitalists boost valuations by recruiting investors to asset circles
}

\author{
Dave Elder-Vass \\ Loughborough University, UK
}

\begin{abstract}
Narratives and conventions have received considerable attention in recent discussions of the valuation of financial assets. Narratives and conventions, however, can only be effective to the extent that they attract and persuade audiences, and this article makes the case for paying more attention to those audiences. In particular, the article argues that financial assets can only be established as assets if there is a group of potential investors that has been persuaded to accept them as such: to take them seriously as potential investments. The article coins the term asset circles to refer to such groups and supports the argument with a discussion of venture capital and its role in the production of unicorns: private companies with extraordinary valuations. Venture capital firms may be thought of as value entrepreneurs, and much of the venture capital process is oriented towards constructing both value narratives for the companies they invest in and asset circles prepared to accept those value narratives. Their aim in these processes is a profitable exit, in which the venture capital firm converts its investment back into cash at a considerable profit through either an acquisition or a flotation.
\end{abstract}

\section{Keywords}

Venture capital, valuation, IPO, conventions, asset circles, assetisation

\section{Introduction}

How do financial assets become valuable? Recent studies of valuation have stressed the work that is done to position goods as valuable (Callon et. al., 2002) using value narratives (Beckert, 2016). There is some recognition that such work is most successful when done by actors with the symbolic power to consecrate value (Bourdieu, 1993), but relatively little attention has been paid to the audiences for these narratives. This article addresses the role of audiences for the value narratives that support financial assets by introducing the concept

\section{Corresponding author:}

Dave Elder-Vass, Loughborough University, Ashby Road, Loughborough, LE11 3TU, UK.

Email: d.elder-vass@lboro.ac.uk. https://doi.org/10.2218/finsoc.v7i1.5588 
of asset circles. An asset circle is a group of potential investors that has been persuaded to take a particular asset seriously as a potential investment. Without asset circles, the article suggests, financial assets are worthless. The article develops the concept of asset circles and then illustrates it through a discussion of venture capital and the valuation of unicorns private companies valued at over a billion US dollars.

The extraordinary valuations of these companies are controversial, not only because they are surprising, but also because of the risks they create for investors and the wider economy (Thrift, 2001). On March 2, 2017, for example, the shares of Snap Inc., the maker of the Snapchat social media app, were launched on the New York Stock Exchange. In 2016, the last year for which results were available at the time, Snap had total revenues of $\$ 404.5$ million and incurred a net loss overall of \$514.6 million (Snap Inc., 2017: 4). Its costs, in other words, were over twice its income, and its own prospectus listed a series of major risks to its future (Snap Inc., 2017: 6). The shares (which were unusual in offering no voting rights to their holders, leaving control of the company in the hands of its founders) were offered at \$17 each and rose $44 \%$ over the first day to close at $\$ 24.48$, valuing the company at $\$ 28.3$ billion (Kuchler and Bullock, 2017).

Such extraordinary valuations of digital businesses are not entirely a new phenomenon. Most strikingly, they were a central feature of the Internet bubble on the US stock exchanges at the beginning of the twenty first century, which saw "a capital market intoxicated by the prospects of digital technologies" (Feng et al., 2001: 468). As Thrift (2001: 425) argued, this bubble was driven in part by "new stories" that established the digital economy as an attractive investment category, and venture capitalists were among the most important forces who drove the boom (Feng et al., 2001: 494).

What is perhaps most surprising is that these extraordinary valuations have returned so soon after the resulting crash and its impact on investors. These valuations have contributed to huge profits for venture capital companies, who have a direct interest in driving them up. Yet in contributing to a series of bubbles in technology stocks they also pose substantial risks for subsequent investors, the larger financial system, and thus for society more widely when these bubbles burst. As Kenney and Zysman (2019: 39) have argued, they also lead to massive misallocations of capital, when unicorns with access to vast amounts of private capital use it to run businesses at a loss, undercutting previously successful businesses and thus "destroying economic value". This is perhaps most striking in its latest iteration, with venture capital driving the growth of platform businesses like Uber which are arguably also "destroying social value while also devaluing labor and work in the enterprise" (Kenney and Zysman, 2019: 39). The processes by which venture capitalists create the valuations that support these activities are thus central to the contemporary phenomenon of platform capitalism (Langley and Leyshon, 2017; Srnicek, 2016). The applied sections of this article examine how such companies come to be valued so highly, paying particular attention to the role of venture capitalists in constructing the value of unicorns and similar companies.

This is a conceptual article, which develops its argument through engaging with public sources and the existing literature on venture capital. Theoretically, it draws on recent work in valuation studies and the economics of conventions, which are discussed in the first section. Its distinctive contribution is to introduce a focus on the audiences for valuation conventions, in particular asset circles: those groups that are persuaded by valuation discourses to consider particular assets as potentially worth investing in. The second section expands on the concept of asset circles, placing it in a critical realist explanatory framework, and discussing its relation to recent work on assetisation. The third section gives an introductory overview of the venture capital process. The remaining sections of the article then look at some of the key 
moments of the process through the lens of the conceptual framework, focusing on venture capital in the US, where it has been most influential.

\section{Financial valuation conventions}

In recent years the study of how things are valued has been revitalised. Despite considerable progress, however, there are still some absences in the prevailing approach. Aspers and Beckert, for example, perceive a neglect of the role of power in valuation and the need to include a politics of classification (Aspers and Beckert, 2010: 23). Their argument connects to the important work of the French economics of conventions school, notably EymardDuvernay's concept of valuation power (Favereau, 2017), and the school's argument that value is in part a product of valuation conventions (Orléan, 2014: 228): collectively shared standards or rules about how to make value judgements (Diaz-Bone, 2017: 245). Aspers and Beckert's argument is that that certain economic actors, typically organisations, exert substantial power over valuation processes. They do so by influencing the valuation conventions that we deploy and "also through the positioning of products under the given regime of devices prevailing in the markets" (Aspers and Beckert, 2010: 23, emphasis in original). If too many scholars of valuation neglect the power of producers and third parties to influence valuation conventions, perhaps even more forget the publics at which this power is directed, not as individuals but as the audience for the discursive work that is done to build support for specific conventions. The implication of this article is that valuation studies requires a broadening of perspective parallel to Stuart Hall's (1973) introduction of the active audience into research on media effects.

The focus of this article is on the monetary valuation of financial assets. As Beckert makes clear, financial markets depend completely on collective beliefs about value, and those beliefs themselves come from narratives "of how and why the prices of indexes, stocks, commodities, or bonds will develop" (Beckert, 2016: 150). These narratives in turn are produced (to serve their own interests) by a broad range of actors, including the companies and governments issuing the securities, investment banks, analysts, ratings agencies, stockbrokers, influential investors, the media, academics and governments. The most successful of these stories become valuation conventions. "Financial markets", Beckert (2016: 148) tells us, are "markets in stories".

Financial value (defined here as the monetary value of financial assets) depends on symbolic narratives that claim certain qualities for the assets concerned and seek to associate them with particular valuation conventions. Hence we can usefully draw on work on symbolic value more generally, notably Pierre Bourdieu's The Field of Cultural Production (1993). His focus here is on the art world and the ways in which cultural products are valued - not primarily in monetary but rather in aesthetic terms, although Bourdieu is always aware of the relation between the two. Nevertheless, much of his argument can be applied very straightforwardly to the financial sector. Transposing this argument quite directly and indeed preserving much of Bourdieu's own language (see Bourdieu, 1993: 37), we may say that financial assets exist as viable investments only if they are known and recognized as such by investors, and so the sociology of financial value must study not only the creation of financial assets but also the symbolic production of their value or, which amounts to the same thing, of belief in their value. It therefore has to consider as contributing to production not only the issuers of securities but also the producers of the meaning and value of the securities, whose combined efforts produce investors capable of knowing and recognizing financial assets and their value. 
Bourdieu recognises that symbolic value depends not only on the creators but also on the consumers of discourses - there is no value without an audience, a public, a circle, that accepts these value claims - and indeed that the work of creating artistic value also operates by building these audiences. Again, the argument applies equally well to financial value. Investment banks, analysts, ratings agencies and the like strive constantly to establish and maintain a reputation that gives them the authority, framed as a kind of financial wisdom, to consecrate securities as having financial value. Those actors who achieve this symbolic authority then collaborate in the effort of consecration that makes the monetary value of financial assets. But this value also depends on having an audience of investors that is capable of understanding their efforts and, to go beyond Bourdieu, a section of this audience that is prepared to accept these value claims - and the work of creating financial value also operates by building this group.

For people or organisations to become potential buyers of a financial asset, they must come to think of it as having value, and this requires it to be linked to a valuation convention that provides a means to estimate that value. Often the most viable way of doing this is to position the asset as falling under an existing theory of value or a closely related variant (Aspers and Beckert, 2010: 23). The product must come to be classified in a way that aligns it as part of, or at least similar to, an existing product category. This can be achieved by building and spreading narratives that make these connections, but this is more viable when the instruments concerned already share some relevant characteristics with the target category, and this in turn is a factor in the design of instruments - they can deliberately be given features that will support the case for linking them to the desired category. The general process of qualification or classification of products has been a central focus of both the economics of convention and the sociological work that it has influenced. Callon and his colleagues, for example, point out that "Economic agents devote a large share of their resources to positioning the products they design, produce, distribute or consume, in relation to others" (Callon et al., 2002: 196).

The benefits of aligning a financial instrument with a particular category are nicely illustrated in Ezra Zuckerman's (1999) article on the coverage of US stocks by securities analysts. In a detailed quantitative study, Zuckerman found that "the stock price of an American firm was discounted to the extent that the firm was not covered by the securities analysts who specialized in its industries" (Zuckerman, 1999: 1398). Unlike most more recent discussions of valuation, Zuckerman places audiences centre stage. For a security to attract a strong valuation in a market, there must be an audience that values it and the security must attract the interest of that audience (Zuckerman, 1999: 1403).

A number of privatisation initiatives provide particularly clear cases of the active construction of such audiences. In the 1980s, for example, the UK government launched major advertising campaigns, notably the 'Tell Sid' campaign related to the privatisation of British Gas, that encouraged hundreds of thousands of members of the public, many of whom had never bought shares before, to subscribe to the issue of shares in the privatised company (BBC, 2011). In the 1990s the German government pursued a similar strategy for the privatisation of Deutsche Telekom, 'promoting its shares as 'Volksaktien' or 'people's shares,' encouraging lots of small investors to get involved and helping to establish a stock investment culture in Germany" (Hornby, 2007: n.p.). More recently the government of Kenya made heavy use of advertising "to stimulate share ownership among new, domestic investors in the frontier stock exchange in Kenya" (Yenkey, 2010: 247). These campaigns broke down barriers to investing in financial assets in general by stimulating members of the public to think that investing might be something for them. But they also focused the attention of potential 
investors on particular investment opportunities and encouraged them to see those investments as good value. This brought these securities to the attention of a wider audience, but in a sense their objective was to build a smaller group that I will call an asset circle: a group of people who are persuaded by the message and as a result see these securities as investments that they might realistically be prepared to purchase.

Similar processes are also used to build asset circles amongst professional investors. We can see this, for example, in the growth of impact investing - "investment with the intentional expectation of social or environmental impact alongside financial return" since 2007 (Barman, 2015: 9). This is a neoliberal-style attempt to substitute market funding of social projects for the state and civil society (Barman, 2015: 10). The Rockefeller Foundation has driven this new market by helping to develop new valuation standards for the non-financial benefits delivered by the companies whose shares were traded in this market - standards that were modelled on "existing market device[s] in traditional capital markets" such as the credit rating agencies (Barman, 2015: 33). The consequence was that investors were able to assess the nonfinancial value of these securities more easily, which in turn helped to build an asset circle of investors prepared to invest in them. By 2014 investments in the market exceeded $\$ 10$ billion (Barman, 2015: 15).

\section{Asset circles}

The concept of an asset circle, introduced in the previous section, may be contrasted with a view implicit in neoclassical accounts of markets, which simply takes for granted that there is a group of economic actors who would be willing to buy any given product, although at varying prices. In a purist marginalist model all actors are assumed to be participants in all markets because they have complete and accurate information about all commodities and prices and respond rationally to them all. In that model there is no need for the concept of an asset circle because every economic actor is automatically open to buying every available asset. But in the real world, people do not have such information and in these circumstances "the range of choices available in the stock market is so large as to utterly swamp and defy rational analysis" (Harrington, 2008: 510). In an example of what Simon (1972) called bounded rationality, they can only function by narrowing down the range of options under consideration.

Different types of investors narrow the range in different ways. At one end of the scale, index funds are committed to investing in the stocks in the relevant index, usually in proportion to their weighting in the index. Their rules automatically make them part of the asset circle for the stocks in the index and exclude them from the asset circles for other assets (perhaps with a little ambiguity at times when stocks move in and out of indexes). Many other investment funds are more flexible but still publicly committed to investing in a certain sector or according to certain rules, which imply that they will monitor and consider investing in any stocks that fit within their rules, and again these are clear members of the asset circles for those stocks (and not for others), even though they do not invest in all of them. More speculative investors such as private day traders and professional traders using algorithmic methods are often also committed to monitoring specific assets with a clear intention to trade when prices meet their criteria.

More generally, most investors specialise in particular types of assets and seek to understand possible investments before deciding whether to invest in them - such as the hedge fund partner observed by Mackenzie and Hardie, who was carefully assessing arbitrage opportunities in the Brazilian government bond market at the time (MacKenzie, 2009: 90-91), 
or the investors who shorted mortgage backed securities by buying credit default swaps in the run up to the 2008 financial crisis (Lewis, 2011).

In this world of limited time and information, the price of an asset with a given supply can be increased by growing the asset circle for it. The concept of an asset circle thus gives us a means to ask questions that usually go unasked: which economic actors are not only aware of but also willing to consider purchasing any given financial asset, and how are they drawn into this group in the first place? It also allows us to go a step further and consider the causal role that such groups and their creation may play in the valuation of assets. We can begin the argument for asset circles from the uncontroversial point that the value of a financial instrument depends on the potential purchaser's expectation that it will entitle them to a revenue stream. Whenever resale of the asset is a significant element of the anticipated revenue stream, this expectation depends in turn on the potential purchaser expecting that there will be other investors willing to buy the instrument at any time when they might wish to resell it. Even in the case of financial assets that are held to maturity by their original purchaser, the possibility of selling the asset prior to maturity may contribute to assessments of its value. In other words, the value of a financial asset to any given purchaser (and therefore, to an extent, the price that can be realised for it) depends, among other things, on the purchaser believing there is an asset circle for it, although they may think of it in somewhat different terms than this: in terms, perhaps, of the existence of a market, or the existence of buyers, or the liquidity of the asset.

Investors can be wrong about such issues, for example if they have been duped by fraudsters into believing that there is such an asset circle when there is not, but most investors are sufficiently cautious that they will only buy assets when they have good evidence to support this belief. This usually requires evidence that the asset concerned, or a closely equivalent asset class, is already being traded and thus that there are already enough potential purchasers to sustain a market in them. In other words, there must usually be an asset circle for an asset or a very good reason to believe that there will be one in the future before investors will buy it.

Positioning this argument in a critical realist framework (Danermark et al., 2019), one may say that financial assets only have value because they have a capacity to be sold, and that this capacity rests on a set of intentional relations between the members of the asset circle (Elder-Vass, 2010). First, the members of the asset circle are willing (an intentional relation) to purchase the instrument as an investment from others in certain circumstances. Second, this intention rests in part on their belief that they themselves will also be able to sell on the financial instrument when required, and this belief in turn depends indirectly on the fact that other members of the asset circle are also willing to purchasing the instrument in certain circumstances. Thus their commitment to membership of the asset circle, which they experience as an intention to consider the asset for purchase, depends on the matching intention (or at least their belief in the matching intention) of others (cf. Gilbert, 1990). Their belief in this matching intention is sustained by the experience of others purchasing the instrument, and thus rests on the iterative nature of practices like these. This is a doubly intentional relation. First, it is a belief about other members of the asset circle, and second, it is a conditional intention to purchase the financial instrument in certain circumstances. These intentional relations give the asset circle an influence that the constituent people and firms would not otherwise have.

Asset circles as such are unobservable. We can only observe the behaviour of their members, those affected by their members, and the work that is done to build them. The existence of an asset circle as an organising structure over and above these actors and 
actions is an ontological hypothesis, an inference from the evidence to the best explanation of the conditions of possibility of the phenomena that we observe. As such, it is an application of the critical realist method of retroduction, employed to hypothesise structures, mechanisms and powers that contribute, in interaction with others, to the causation of events (see ElderVass, 2007). Because they are unobservable, we cannot measure or count asset circles using traditional quantitative methods, nor can we prove their existence by examining the meanings available to interpretivist researchers. Instead, like other hypotheses about unobservables, we can only assess the validity of the argument by considering how well it coheres with the evidence available. Because we cannot observe the structures and mechanisms themselves, we have to ask what we would observe if they existed and acted as hypothesised (a method widely practiced in the natural sciences). If we find evidence that fits, the hypothesis is supported - though not proven - while if we find none, or if we find countervailing evidence, it is not.

If asset circles are real and causally significant, we should be able to find evidence about how they are constructed. On the argument that investors do not automatically become open to investing in any new putative financial asset, we would expect to find efforts being made by value entrepreneurs to recruit investors into the corresponding asset circles. Every asset circle, in other words, must have a causal history, unlike the perfectly informed investors of marginalist theory; and by studying those causal histories we should find evidence that coheres with the hypothesis of their existence. Hence the discussion of venture capital in the later parts of this article can contribute to assessing the plausibility of the asset circles hypothesis.

Perhaps the section of the contemporary valuation literature that approaches most closely to the issues raised here is the innovative recent work on the concept of assetisation (Birch, 2017; Birch and Muniesa, 2020b; Muniesa et al., 2017). This literature asks a similar question to that examined above: how are assets constructed as assets (Birch and Muniesa, 2020a: 2)? It tends to approach it through the empirical study of cases, often at the microinteractionist level, whereas I have argued from a broad range of existing evidence to an ontological hypothesis about the conditions of possibility of financial assets. The assetisation literature has made important advances in both recognising the increasing contemporary importance of financial assets and examining how they come into existence. The ontological arguments do not supplant but rather complement these findings and build on them by adding concepts that are empirically relevant even though they may not be empirically obvious.

While audiences are not generally treated as central to assetisation in this literature, neither are they entirely ignored. Birch's (2017) article on assetisation in the biotech sector, for example, provides some interesting interview material with a venture capital investor who tells us how important it is for them to manage investor sentiment (see especially Birch, 2017: 48081). Ouma (2018) has investigated how farmland asset managers have sought to persuade institutional investors to take farmland seriously as an investment. Williams (2020) examines the challenges faced by social impact bond practitioners in engaging and recruiting investors. Birch and Muniesa's introduction to their collection on assetisation tells us that "the urge to attract investors becomes a crucial political imperative" (Birch and Muniesa, 2020a: 20), but doesn't say much more about the issue, and the slightly distant relation of most of the assetisation literature to the construction of asset circles is captured nicely in Muniesa et al.'s collective work on capitalisation (a word that they use as a synonym of assetisation):

Capitalization, considered as a transitive process of valuation, requires some sort of a focal point - a gaze - from which to make sense of the answer to the "for whom" question. This is the investor, a free investor 
that we have characterized as a persona, a figure, rather than as an actual somebody, a virtual investor whose gaze needs to be adopted by actual people. (Muniesa et al., 2017: 1957)

Other strands of the valuation literature have also engaged occasionally with the issues raised by the asset circles hypothesis. Harrington's work on investment clubs, in particular, provides a rare but substantial engagement with private investors, examining how they select stocks and how this is influenced by the various "signals and symbolic communication that firms are directing toward the market" (Harrington, 2008: 613). Thrift (2001) also takes private investors seriously, although his work is oriented more to how they were persuaded to take a whole new class of stocks seriously, rather than any one stock in particular.

To summarise the theoretical argument: the value of assets depends, among other things, on how many people or other social actors see them as a potential purchase, that is, on the size of the asset circle for the type of asset concerned. Whether or not an individual member of the asset circle does decide to buy the asset depends on further factors, such as how the price of the asset compares to the valuation the potential buyer places on it, and thus on the valuation conventions that she is employing, but to be motivated to make such assessments the actor must already be a potential buyer, a member of the asset circle for the asset concerned. Asset circles, in turn, are built by discursive processes in which value narratives persuade individuals of the potential merits of a type of asset. Let us turn now to how this framework of value narratives, valuation conventions and asset circles helps to illuminate the venture capital process.

\section{The venture capital process}

Venture capital (VC) funds in the United States are typically organised in the legal form of limited liability partnerships. They raise funds from outside investors (known as the limited partners), invest those funds in private companies (i.e., companies whose shares cannot be purchased on a public stock exchange), and aim to grow the companies in their portfolio so that they can sell on their stake at a large profit. Much of the funding is provided by pension funds (44\% in the US since 1980) followed by financial institutions like banks and insurance companies (18\%) and endowments and foundations (17\%) (Metrick and Yasuda, 2010: 27-28). The investment process is controlled by the general partners - the people we normally think of as venture capitalists - who manage the fund, identify suitable companies to invest in, work with those companies, and look for profitable exit opportunities (Sahlman, 1990). Venture capital funds are time-limited, typically lasting ten years from initial funding to closing the fund, and because investments are spread over the first few years of this period, general partners usually aim to exit investments in companies in their portfolio in significantly less than ten years. They therefore tend to invest only in companies with prospects for rapid growth, with the result that they have been particularly focused on technology companies. Indeed two thirds of the top US venture capital firms are based in Silicon Valley in California (Metrick and Yasuda, 2010: 87-88), where they have been deeply involved in the explosion of Internetrelated technology companies over the last few decades (Zook, 2005). Silicon Valley attracted as much VC funding as the next four US regions combined all the way through from 1981 to 2017 (Kenney and Zysman, 2019: 37).

Venture capital began as a US phenomenon and although venture capital is becoming increasingly important elsewhere, notably in China, this article focuses on US cases as these are the most thoroughly documented in the literature so far. The amount of capital committed to VC funds in the US grew steadily from $\$ 4.1$ billion in 1980 to $\$ 40.6$ billion in 1995 and 
much more rapidly to $\$ 253$ billion in 2001 , then stabilised at roughly this level for several years after the collapse of the Internet stock bubble (Metrick and Yasuda, 2010: 24).

There is enormous variation in the success of venture capital investments (Langley and Leyshon, 2017: 24). Many fail - around 49\% of VC portfolio companies are defunct within ten years (Metrick and Yasuda, 2010: 125). The rest are sold. Some are acquired by larger businesses, at a range of prices reflecting the potential of the firm's product. At the bottom end of this range, companies may be bought solely in order to acquire their staff to deploy in other projects. The target outcome for the venture capitalist, however, has traditionally been to sell their stake in the portfolio company at a huge profit, either in a lucrative acquisition or by launching their shares in an initial public offering (IPO) on the stock exchange, like the Snap IPO that introduces this article (Gompers and Lerner, 2006: 7-8; Metrick and Yasuda, 2010: 124-34). Recently some unicorns, notably Uber, have remained private for considerably longer, seeking to build a monopolistic position in a platform business by drawing on larger amounts of private capital, although it remains to be seen how this will play out over the longer term. Because of this range of possible outcomes, venture capital funds are rather risky investments, and VC firms can only attract investment in later funds by delivering high returns to their limited partners in earlier ones. This means that they need to make exceptional profits on their most successful investments to recover the costs of the failures and the run of the mill cases where portfolio firms deliver only ordinary levels of profit. In the most extreme cases, returns can be spectacular. The most successful venture capital investment in history is generally believed to be Benchmark Capital's investment in eBay. According to one estimate, this generated a profit of $\$ 2.5$ billion for the fund on an investment of $\$ 5$ million (Metrick and Yasuda, 2010: 89, 126; for another estimate, see Stross, 2000: xv). The remainder of this article picks out some key moments in the venture capital cycle and in particular the version of it that leads to an IPO, in order to examine how the value of shares in portfolio companies is constructed.

\section{Buying into the business}

The first value narratives constructed in the venture capital process take the form of business plans prepared by the owners of firms seeking an investment. Metrick and Yasuda (2010) estimate that for every investment VCs make they see of the order of 1,000 business ideas. Perhaps 100 of those receive some formal attention and only a handful enter the negotiation process (Metrick and Yasuda, 2010: 135-36). Few make much progress without a business model - a speculative narrative about the future earning potential of the firm given a gloss of legitimacy by the employment of quantification and calculation. As Doganova and Muniesa (2015: 113) put it, the purpose of such models is to "enrol allies". To be more specific, the purpose is to expand the asset circle for shares in the company by persuading venture capitalists to take the company seriously as a potential investment.

The firm's own business model will rarely be taken at face value by the venture capitalist, who is more likely to see a persuasive business plan as an indicator of business competence than a reliable forecast (Muniesa et al., 2017: 1043-88). Instead, it will be reworked by the venture capitalist to arrive at her own valuation of the firm, though again this inevitably remains a speculative narrative. There are two broad methods employed - two valuation conventions - known as absolute valuation and relative valuation (Metrick and Yasuda, 2010: 179-80). In absolute valuation, the future cash flows of the business are forecast and discounted to produce an estimate of its net present value (Chiapello, 2015). This method is advocated by purists like Damodaran (2018) but it arguably fails to capture what matters to 
the venture capitalist. For them, cash flows matter only as far as they affect the price that can be realised for the company's stock, and as numerous Internet companies have shown, heavy losses are not necessarily an obstacle to a lucrative flotation. Indeed, for platform companies seeking market dominance, heavy losses have become part of the standard growth model (Kenney and Zysman, 2019). Relative valuation, by contrast, involves valuing a company by comparing it with other similar companies - by aligning it with an existing category. Snap, for example, could be valued by comparing it with Facebook, another social media company that makes its money from advertising, currently (August 2020) valued by the stock market at over $\$ 800$ billion. Snap's current valuation reflects the market's belief, or hope, that it may someday be able to raise advertising revenue that reflects the relative size of its user population and Facebook's. For a venture capitalist, what matters is the exit price, and in the case of Snap, it is clear that the exit price would have been more accurately reflected by using relative rather than absolute valuation methods. That exit price in turn, however, rested on persuading potential investors at the time of the IPO to adopt the relative valuation convention, and so the prospects of establishing such valuation narratives for their potential investments are also an important consideration.

It is unusual for a portfolio company to need only one round of venture capital funding, indeed venture capitalists prefer to release funding in a series of rounds, enabling them to make their commitment contingent on progress in growing the company (Freeman, 2005: 152). At each stage, that progress should lead to a higher valuation for the company, but at each stage the venture capitalist will also expect to take a further stake in the company in return for the new investment, and it is common for the original owners to progressively lose control of their companies as a result (Freeman, 2005: 161-63).

It is also common for the lead venture capitalist to involve other venture capitalists in later rounds (known as syndication), where they share the investment and thus both the risk and the potential reward. One benefit of this is that "other venture firms [provide] a second opinion on the investment opportunity" (Gompers and Lerner, 2006: 167). Indeed, for syndication to occur, the different venture capitalists involved must agree on a valuation for the firm, and thus also on the applicability of the conventions used to value it. This is therefore a step towards establishing both a larger asset circle and also a more public valuation of the firm. It is striking that later funding round valuations are often made fully public, in sharp contrast to the secrecy with which the rest of venture capital performance is surrounded (Hook, 2016; Metrick and Yasuda, 2010: 46). Thus, for example, Xiaomi announced in December 2014 that it had raised $\$ 1$.1billion in a new funding round, valuing the company at $\$ 45$ billion (BBC, 2014), and Airbnb announced in March 2016 that it had raised $\$ 1$ billion, valuing it at $\$ 30$ billion (Hook, 2017).

It is hard to avoid the conclusion that these valuation announcements are part of a deliberate strategy to build expectations about the value of the firm in the public market, in preparation for a future IPO, thus starting to build a broader circle that is open to valuing the company in line with the venture capitalists' chosen conventions. As one commentator has put it, "Financial experts refer to these headline valuations as 'marketing numbers', highlighting that they are a function of image as much as anything else" (Hook, 2015: n.p.).

One especially remarkable case was an investment by SoftBank into Uber in 2017. The deal was structured so that SoftBank bought new shares at the same valuation as the previous funding round, nominally maintaining Uber's headline value of $\$ 68$ billion, but at the same time (and as a condition of the deal), SoftBank also bought shares from existing investors at a substantially lower price, so that the average price they were paying for a share implied a significantly lower overall value for Uber (Waters, 2017). Investors in Uber thus 
sought to maintain the apparent public value of their shares at a higher level than they accepted in a private sale.

\section{Building the business}

Having acquired a stake in a portfolio firm, venture capitalists typically provide practical support to help the firm grow, primarily in the forms of advice and of introductions to important business connections. According to Metrick and Yasuda (2010: 9-10), "Many VCs argue that these activities provide the best opportunity to add value and are the main source of comparative advantage for a successful VC". Conventionally the value of these contributions is seen as internal, as helping the company to become more capable of building its revenues and controlling its costs. However, there is a second aspect which is equally important: these activities contribute not just to building the business but also to building the reputation of the business.

The most striking way in which this is done is by association. Successful venture capitalists themselves have a reputation for launching successful companies, and having such a venture capitalist as an investor is already a mark of approval from a symbolic authority of financial value, a "consecration" of its potential value, to use Bourdieu's (1993: 78) term. But venture capitalists also build networks of other symbolic actors in the field and deploy them in the task of consecration. Thus, for example, not only do venture capitalists take seats on the board of their portfolio companies, but they may also bring in other board members, typically highly successful people whose very presence adds to the reputation of the firm. Objectively small firms with little or no history of profits can be rapidly elevated in the hierarchy of evaluations simply by appointing a billionaire or a former government minister to the board of directors.

Similarly, venture capitalists often bring in new executives, including CEOs, to drive forward a portfolio company (Hellmann and Puri, 2002; Metrick and Yasuda, 2010: 97). Again, these may have stellar reputations out of all proportion to the current standing of the company (a process that is assisted by giving them substantial stock options). Benchmark Capital, for example, recruited Meg Whitman from a job running a \$600 million a year division of the world's largest toy company to take over as CEO of eBay in 1997 when its revenues were still a tiny fraction of that (Stross, 2000: 55-60). Not many stock option packages work out quite this well; by 1999, the options she received were worth over $\$ 1$ billion (Stross, 2000: 216). Press releases follow, and other investors start to notice companies that would otherwise have stayed below their radar or raise their expectations of the company's future performance. Venture capitalists may also introduce their portfolio companies to highly regarded potential customers and suppliers, such as "bankers, law firms, accountants, and executive search firms" (Freeman, 2005: 153). These may sometimes provide better services than less wellknown competitors, but more importantly, they help to raise the reputation - by association with their symbolic capital - of the portfolio firm.

The general public and smaller investors may be unaffected by these moves, but reputations are specific to audiences, and for a venture capitalist tending a company destined for an IPO, the audience that matters is the large institutional investors who might be persuaded to buy substantial blocks of shares when they come to the market. This is exactly the audience that is likely to be impressed by big name directors, executives, and suppliers, whom they may already interact with in other contexts.

The networks that venture capitalists put in place, then, contribute to building the reputation of their portfolio firms among potential future purchasers of their stock. They are 
implicitly responding to a valuation convention that is prevalent in this population: that companies with familiar and respected executives, board members, investors and suppliers are good investments, and worth more than those without them.

\section{Approaching the IPO}

One route to a highly profitable exit for the venture capitalist is to launch the shares of the portfolio firm on the stock market in an initial public offering and then sell their own shares into the public market this creates. Usually venture capitalists are not allowed to sell their own stake during the initial offering, but rather must hold it for a lock up period of perhaps 4 or 6 months after the IPO. Hence the IPO itself is not an exit event for the venture capitalist, but it creates the conditions in which they will exit their investment, and makes a crucial contribution to determining the price at which they will eventually be able to sell. This section will consider how venture capitalists approach the IPO process, and the next will look at IPO outcomes and VC exits.

The IPO process is heavily regulated, particularly in the United States, with strict rules about what must be divulged during the period running up to the IPO, in a prospectus including properly audited accounts, sales history, and full disclosure of the risks facing the business. Other written communications from and about the issuing firm are heavily restricted during this period to avoid the spread of misleading information. The business, however, can be marketed to potential institutional investors at events known as roadshows run by the investment bank that is handling the IPO. As the venture capitalist Gus Fuldner of Benchmark Capital puts it,

The roadshow is an opportunity for management to tell the story behind the numbers in the prospectus and to answer questions to improve investors' understanding of the business and the information contained in the prospectus. (Fuldner, 2012: n.p.)

Telling 'the story behind the numbers' takes on a new significance when the numbers are as unfavourable as those reported by Snap. Snap, however, is only one of many information technology firms that have been brought to market over the last two decades with negative earnings and radically uncertain prospects (Morgan, 2008: 57-60). In such cases those behind the IPO need to construct a value narrative to justify the proposed valuation of the business. Biotech companies have often followed a similar pattern (Birch, 2017: 461-62). Here, the narrative is generally that they are developing a new medical treatment and thus have heavy research and development costs until they can begin licensing the treatment to a manufacturer. Many biotech firms never succeed in making a profit, but a few make very large profits (Birch, 2017: 471-72), and the narrative for new firms must be constructed in such a way as to align the public view of the business with those favourable comparators.

Indeed, this is also the hope for digital technology firms - investors in firms like Snap are betting that it will be the next major financial success story like Facebook, and the narratives built around Snap encourage this belief. Evan Spiegel, for example, the co-founder and chief executive of Snap, argued in August 2017 (in this case after Snap's IPO - public communications in the pre IPO period are very limited so direct evidence of the narratives advanced in this period is hard to come by) that investors should pay more attention to the average revenue per user earned by the company. For Snap this was $\$ 1.05$, and for Facebook $\$ 4.73$, and the clear implication was that Snap could be expected to drive up its revenues per user to a comparable level (Lex, 2017b). 
Prospectuses, roadshows, and the value narratives constructed to support IPOs have two broad objectives. The first is to build the asset circle for the stock: a set of investors who are persuaded that the firm is a legitimate investment with promising prospects and are therefore prepared to consider investing in it. There is a sense in which these asset circles are segmented: there is an 'insider' segment of financial institutions that disposes of the most capital and at which pre-IPO communications are directed. Meanwhile the media and particularly the financial press provide communication to the 'outsider' segment of private investors, who may also develop some enthusiasm for the stock, particularly if it is a consumer-oriented company with high public visibility. The second objective is to establish belief amongst the asset circle on the applicability of particular categorisations and valuation conventions to justify a target price for the stock (in the case of Snap, comparability to Facebook). It is not only the narrative itself that counts, but also who delivers it: in another case of exploiting reputational capital, venture capitalists tend to appoint high status investment bankers to act as advisors and underwriters for their IPOs, exploiting the networks of contacts and previous interactions these bankers have with large institutional investors.

While prospectuses are public, much of this process is carried through behind the scenes by the bookbuilders for the IPO - underwriters, usually employed by the investment banks, who consult institutional investors to establish what prices they might be willing to pay for the new shares and construct an order book for them (Ritter, 2011: 8-9). While investors' decisions are based on how profitable they believe the purchase will be, their expectations of profits are influenced by the credibility of the various actors involved in the IPO process. In addition to the firm's executives and directors, these include the venture capitalists themselves. Gompers and Lerner, for example, argue that established venture capitalists build up reputational capital by bringing firms to market at fair value, and so their presence acts to certify the quality of the firm to investors (Gompers and Lerner, 2006: 347-48). They also include the investment banks advising the firm on its offering and the underwriters themselves, whose reputations also function as certifying mechanisms (Chemmanur and Krishnan, 2012: 770). Snap's IPO, for example, was led by Morgan Stanley, named by the Financial Times as "the top US tech IPO bank in five of the last seven years" (Kuchler, 2017: n.p.). Megginson and Weiss found that "VC backed firms have higher quality underwriters and auditors as well as a larger institutional following than do non-VC backed offers" (Megginson and Weiss, 1991: 892).

The underwriters will test a range of possible prices with investors, then before the public market opens set the official offer price at which the stock will be sold to subscribing investors (Chemmanur and Krishnan, 2012: 770). Investors may then apply to the underwriters to buy blocks of stock, so that the new stock can be placed in an orderly fashion with subscribers at a fixed price rather than waiting for the market to open. Often the offer is oversubscribed, meaning that investors want to buy more shares than the issuing company is ready to offer. In such cases institutional investors receive only a part of the allocation they have bid for, and typically the share price will rise once the market opens.

These outcomes, however, are never guaranteed, as demonstrated by the spectacular failure of the proposed \$47 billion IPO of WeWork in 2019 (Edgecliffe-Johnson and Badkar, 2019). WeWork had constructed a narrative that positioned it as a new technology company that was going to transform the world of work, but the vast majority of its actual (heavily loss making) business consisted of renting and then re-letting office space. While the collapse of the IPO was also blamed to some extent on governance issues, the failure to convince potential investors of the valuation narrative meant that the underwriters were unable to build an asset circle for the stock amongst institutional investors (Platt and Fontanella-Khan, 2019). 


\section{The IPO and after}

Having set an offer price for those institutional investors that have made firm orders in advance of the market opening, the underwriters also act as market makers - that is, they agree to buy and sell stock on the open market after the IPO, adjusting the price as orders come in. On the opening day they will assess demand for the share before setting an opening price, which is often higher than the offer price. The price will then move in response to supply and demand, and initial public offerings are generally judged on the closing price at the end of the first day of trading. For example, Snap's shares were offered to advance investors at \$17, but the market opened at $\$ 24$ and closed on the first day at $\$ 24.48$, an increase of $44 \%$ over the offer price (Kuchler and Bullock, 2017). Annual average first day returns for US IPOs have rarely dropped below 10\% since 1990 and have occasionally been much higher, peaking at 70\% in 1999 (although not all IPOs are underpriced) (Ritter, 2011: 5). At least part of the explanation for this is that individual private investors are unable to obtain allocations of shares in advance of the IPO, and so if they have been drawn into the asset circle for the stock on the basis of the pre-IPO publicity this is their first opportunity to buy shares.

The venture capitalist's interest in a firm is by no means over when the IPO is complete, because lock-up provisions in the contract with the underwriters usually prevent them (and the portfolio firm's founders and staff) from disposing of their own shares until sometime after the IPO, typically 180 days later, although underwriters may allow some sales during the restricted period (Gompers and Lerner, 2006: 424-26).

While their stock is locked up (and indeed after the lock up period if they retain shares beyond it), the venture capitalist and the firm's managers have a continuing interest in the maintenance of the firm's share price, which can vary enormously over the course of the period, particularly where the basis of the firm's valuation is highly uncertain and thus the share price is particularly vulnerable to changing sentiment amongst potential investors. Snap's share price, for example, varied between 73 percent over its offer price and 30 percent below it over the course of the first year of trading (and its three lock-up periods; Singer, 2018). Venture capitalists remain actively involved in discursive work to sustain the value of their investment. Birch (2017: 480-81), for example, quotes one venture capitalist investor in biosciences companies as saying that "you've got to spend a huge amount of time managing sentiment and, you know, maintaining investor interest" once a firm has launched on the stock market. The portfolio firm's managers will also be involved - Evan Spiegel's comments on Snap's valuation noted earlier, for example, were made during the lock-up period on its shares.

Insiders, however, do not have a monopoly on value narratives, particularly once a company has gone public. In particular, stock analysts, many of them employed by investment banks, research companies and issue reports assessing their valuation for the benefit of potential investors. These may adopt and further legitimise the narratives generated by the venture capitalists and the firm itself, or they may dispute them. Although it is common for different analysts to take different stances, when the balance of recommendations tips strongly to one side or another they do shape the discursive environment and influence decisions. For example, the initial response of the analysts to Snap's IPO was overwhelmingly negative (Lex, 2017a). Indeed the first analyst to issue a sell rating gave a target price of just $\$ 10$, versus the offer price of $\$ 17$ and the opening price of $\$ 24$, describing the company as "promising" (Bullock and Kuchler, 2017) but "significantly overvalued" (Kuchler and Bullock, 2017). Within three days of the IPO, Snap's stock price had dropped below the initial opening price and as at August 2020 it has stayed there ever since other than a short period in July 2020 , currently trading at around $\$ 22$ after having dropped as low as $\$ 5$ towards the end of 2018. 
Analysts, however, are not necessarily objective sources of opinion. In particular, the analysts employed by the underwriters involved in an IPO are known for giving upbeat recommendations on the stocks launched by their employers, typically publicising favourable value narratives and linking the stock to favourable valuation conventions while ignoring or downplaying narratives of overvaluation (Ritter, 2011: 15). The US Securities Exchange Commission prohibits analysts affiliated to IPO underwriters from publishing research for 40 days after the launch but when this quiet period is over, the underwriters' analysts are free to publish (Bradley et al., 2004). In the case of Snap, for example, as the Financial Times put it:

Then on Monday came a flurry of "buy" ratings. Who were these gallant heroes, riding to the rescue of the besmirched Snap and boosting its worth by 5 per cent to almost $\$ 28 \mathrm{bn}$ ? It was the underwriters, who had waited for a quiet period to elapse before publishing. (Lex, 2017a: n.p.) .

Indeed it has been argued that one of the motivations for venture capitalists to choose specific underwriters is precisely that they have influential analysts who can issue positive research on the company being floated (Liu and Ritter, 2011). The prospect of securing favourable coverage from multiple influential analysts also appears to be one reason why many VCs engage multiple underwriters for an IPO (Liu and Ritter, 2011: 586). For smaller firms, getting analyst coverage at all is an important step towards establishing an asset circle for the firm's stock, and venture capitalists can sometimes use their network and their reputation to secure analyst coverage for their portfolio firms when they IPO (Gompers and Lerner, 2006: 484-85). There is also considerable evidence that increased analyst coverage has a positive impact on a firm's share price (Liu and Ritter, 2011: 582).

As we have seen, the lock-up provision means that venture capitalists and the issuing firm's staff have no direct interest in the IPO price. Instead, they are interested in the price at the end of the lock-up period, and there is evidence that underwriters' analysts "are especially likely to release a positive recommendation shortly before the lockup period expires" (Ritter, 2011: 15). This is particularly useful to the inside investors as the share price often falls at the expiration of the lockup period due to the release of more stock onto the market (Gompers and Lerner, 2006: 424).

\section{Conclusion}

According to the orthodox account of valuing financial assets, each asset has an intrinsic value that can be obtained by discounting reliable estimates of future cash flows. But as Jens Beckert (2016) has pointed out, all estimates of future cash flows are fictions. We must therefore ask why investors do buy assets. The valuation literature has demonstrated that value narratives play a key role in persuading them, but how does this process work?

On one hand, we must recognise the interests and the power of the institutions that generate and propagate these narratives. For unicorns, it is primarily venture capitalists and investment banks that play this role, and their discursive power arises from their accumulated social and symbolic capital - the networks of connection and obligation that they have built up with other financial institutions, and their reputations with the wider investment community. Potential investors may or may not be convinced by valuation stories, and this depends not only on the cogency of the argument but also on how much trust they place in the people telling the stories. Institutional investors in particular tend to place their trust in the representatives of other financial institutions, and so tend to be persuaded by the stories they hear from respected investment banks, their underwriters and analysts, by venture capitalists 
with reputations for launching successful shares in the past, and by companies whose representatives have already acquired a reputation as effective business people.

On the other hand, narratives can have no effect whatsoever unless they have audiences and those audiences are persuaded by them. In the case of these financial valuation narratives, to be persuaded is first to join the asset circle for the asset concerned, or in other words to become open to investing in it. Second, it is to assess the price at which one is willing to buy in terms of the valuation narratives being advocated. While authors like Beckert have started to introduce considerations of the power of institutions into the financial valuation literature, there has been relatively little attention to the role of audiences, and the primary contribution of this article is to introduce the concept of asset circles in order to theorise the crucial role of audiences in the valuation process. It argues that we can better understand the valuation of financial assets in general, and startups adopted by venture capitalists in particular, by paying more attention to the work that is done by their promoters to build circles of willing investors. Future academic work on financial assets would benefit from engaging with audiences in more depth and thus testing the value of the asset circles concept.

In weaving their stories and deploying their symbolic capital to gather asset circles for their products, venture capitalists have played the central role in a process of diverting huge amounts of capital into funding the so-called new economy (Kenney and Zysman, 2019; Thrift, 2001). In the process they have created massive risks - of losses for ordinary investors in the stocks they have promoted, and of the destruction of businesses and jobs in the collapse that will follow when the bubble bursts. Indeed, with the recent focus on sinking capital into platform economy businesses running at a loss to disrupt established business sectors, they are now destroying businesses and jobs even before such a collapse. By recognising that this process depends utterly on building an asset circle, we can see how fundamentally these harms depend on the complicity of investors in the stories woven by venture capital and their bankers.

\section{Acknowledgements}

I am extremely grateful to the Independent Social Research Foundation, which generously funded part of this work through a Political Economy Research Fellowship. I would also like to thank Bruce Carruthers, two conference audiences, two anonymous reviewers and the editors of Finance and Society for their very useful comments on earlier drafts.

\section{References}

Aspers, P. and Beckert, J. (2010) Value in markets. In: Beckert, J. and Aspers, P. (eds.) The Worth of Goods: Valuation and Pricing in the Economy. Oxford: Oxford University Press, 3-38.

Barman, E. (2015) Of principle and principal: Value plurality in the market of Impact Investing. Valuation Studies, 3(1): 9-44.

BBC (2011) Thousands 'told Sid' 25 years ago. BBC News, 21 November. Available at: <http:// www.bbc.co.uk/news/business-15792873>. Accessed 4 October 2017.

BBC (2014) Xiaomi most valuable tech start-up. BBC News, 30 December. Available at: <https:// www.bbc.co.uk/news/business-30629883>. Accessed 4 June 2018.

Beckert, J. (2016) Imagined Futures: Fictional Expectations and Capitalist Dynamics. Cambridge, MA: Harvard University Press.

Birch, K. (2017) Rethinking value in the bio-economy: Finance, assetization, and the management of value. Science, Technology, \& Human Values, 42(3): 460-90. 
Birch, K. and Muniesa, F. (2020a) Introduction: Assetization and technoscientific capitalism. In: Birch,

K. and Muniesa, F. (eds.) Assetization: Turning Things into Assets in Technoscientific Capitalism. Cambridge, MA: MIT Press, 1-41.

Birch, K. and Muniesa, F. (eds.) (2020b) Assetization: Turning Things into Assets in Technoscientific Capitalism. Cambridge, MA: MIT Press.

Bourdieu, P. (1993) The Field of Cultural Production. Cambridge: Polity Press.

Bradley, D.J. et al. (2004) The IPO quiet period revisited. Journal of Investment Management, 2(3): 111.

Bullock, N. and Kuchler, H. (2017) Snap drops 12\% to close below Thursday's opening price. Financial Times, 7 March. Available at: <https://www.ft.com/content/a4b645ee-02b2-11e7-aa5b$6 b b 07 f 5 c 8 e 12>$. Accessed 1 June 2018.

Callon, M. et al. (2002) The economy of qualities. Economy and Society, 31(2): 194-217.

Chemmanur, T.J. and Krishnan, K. (2012) Heterogeneous beliefs, IPO valuation, and the economic role of the underwriter in IPOs. Financial Management, 41(4): 769-811.

Chiapello, E. (2015) Financialisation of valuation. Human Studies, 38(1): 13-35.

Damodaran, A. (2018) The Dark Side of Valuation: Valuing Young, Distressed, and Complex Businesses. Third edition. Indianapolis, IN: Pearson FT Press.

Danermark, B. et al. (2019) Explaining Society: Critical Realism in the Social Sciences. Second edition. Abingdon: Routledge.

Diaz-Bone, R. (2017) Classifications, quantifications and quality conventions in markets. Historical Social Research, 42(1): 238-62.

Doganova, L. and Muniesa, F. (2015) Capitalization devices: Business models and the renewal of markets. In: Kornberger, M. et al. (eds.) Making Things Valuable. Oxford: Oxford University Press, 109-25.

Edgecliffe-Johnson, A. and Badkar, M. (2019) WeWork to formally withdraw IPO filing. Financial Times, 30 September. Available at: <https://www.ft.com/content/a18aa1a0-e390-11e9-b1129624ec9edc59>. Accessed 29 April 2020.

Elder-Vass, D. (2007) A method for social ontology. Journal of Critical Realism, 6(2): 226-49.

Elder-Vass, D. (2010) The Causal Power of Social Structures. Cambridge: Cambridge University Press.

Favereau, O. (2017) Hommage à François Eymard-Duvernay. Revue Française de Socio-Économie, 18: 5-12.

Feng, H. et al. (2001) A new business model? The capital market and the new economy. Economy and Society, 30(4): 467-503.

Freeman, J. (2005) Venture capital and modern capitalism. In: Nee, V. and Swedberg, R. (eds.) The Economic Sociology of Capitalism. Princeton, NJ: Princeton University Press, 145-67.

Fuldner, G. (2012) How does an IPO roadshow not violate SEC ‘quiet period' rules? Available at: <https://www.quora.com/How-does-an-IPO-roadshow-not-violate-SEC-quiet-period-rules>. Accessed 24 May 2018.

Gilbert, M. (1990) Walking together. Midwest Studies in Philosophy, XV: 1-14.

Gompers, P. and Lerner, J. (2006) The Venture Capital Cycle. Cambridge, MA: MIT Press.

Hall, S. (1973) Encoding and decoding in the television discourse. Council of Europe Colloquy on 'Training In the critical reading of televisual language'. Leicester: Centre for Cultural Studies, University of Birmingham.

Harrington, B. (2008) Pop Finance: Investment Clubs and the New Investor Populism. Princeton, NJ: Princeton University Press.

Hellmann, T. and Puri, M. (2002) Venture capital and the professionalization of start-up firms: Empirical evidence. The Journal of Finance, 57(1): 169-97. 
Hook, L. (2015) Unicorns face end of the 'steroid era'. Financial Times, 10 November. Available at: <https://www.ft.com/content/6ad992e6-8792-11e5-9f8c-a8d619fa707c>. Accessed 23 May 2018.

Hook, L. (2016) Investors' need for start-up knowledge spurs new breed of analyst. Financial Times, 6 September. Available at: <https://www.ft.com/content/61de9980-7093-11e6-9ac11055824ca907>. Accessed 23 May 2018.

Hook, L. (2017) Airbnb completes \$1bn fundraising to support expansion. Financial Times, 9 March. Available at: <https://www.ft.com/content/Ofde09e0-04ef-11e7-ace0-1ce02efOdef9>. Accessed 04 June 2018.

Hornby, C. (2007) German household investors hug sidelines. Reuters, 1 August. Available at: <https:// uk.reuters.com/article/lifestyle-germany-stocks-risk-dc-idUKL1978588820070801>. Accessed 26 August 2020.

Kenney, M. and Zysman, J. (2019) Unicorns, Cheshire cats, and the new dilemmas of entrepreneurial finance. Venture Capital, 21(1): 35-50.

Kuchler, H. (2017) Snap downgraded by lead IPO underwriter as shares fall. Financial Times, 11 July. Available at: <https://www.ft.com/content/a10f4b28-663c-11e7-9a66-93fb352ba1fe>. Accessed 24 May 2018.

Kuchler, H. and Bullock, N. (2017) Snapchat owner closes up 44\% for \$28.3bn valuation. Financial Times, 2 March. Available at: <https://www.ft.com/content/89f1a01a-ff55-11e6-96f83700c5664d30>. Accessed 21 May 2018.

Langley, P. and Leyshon, A. (2017) Platform capitalism: The intermediation and capitalization of digital economic circulation. Finance and Society, 3(1): 11-31.

Lewis, M. (2011) The Big Short: Inside the Doomsday Machine. London: Penguin.

Lex (2017a) Snap: Evanescent analysts. Financial Times, 31 March. Available at: <https://www.ft.com/ content/56f1620e-1332-11e7-b0c1-37e417ee6c76>. Accessed 01 June 2018.

Lex (2017b) Snap: hangdog billionaire. Financial Times, 10 August. Available at: <https://www.ft.com/ content/8c1dd068-7e1f-11e7-ab01-a13271d1ee9c>. Accessed 24 May 2018.

Liu, X. and Ritter, J. R. (2011) Local underwriter oligopolies and IPO underpricing. Journal of Financial Economics, 102(3): 579-601.

MacKenzie, D. (2009) Material Markets: How Economic Agents Are Constructed. Oxford: Oxford University Press.

Megginson, W.L. and Weiss, K.A. (1991) Venture capitalist certification in initial public offerings. The Journal of Finance, 46(3): 879-903.

Metrick, A. and Yasuda, A. (2010) Venture Capital and the Finance of Innovation. Second revised edition. New York: John Wiley \& Sons.

Morgan, J. (2008) Private Equity Finance: Rise and Repercussions. Basingstoke: Palgrave Macmillan. Muniesa, F. et al. (2017) Capitalization: A Cultural Guide. Paris: Presses des Mines.

Orléan, A. (2014) The Empire of Value: A New Foundation for Economics. Translated by Debevoise, M.B. Cambridge, MA: MIT Press.

Ouma, S. (2018) This can('t) be an asset class: The world of money management, "society", and the contested morality of farmland investments: Environment and Planning A: Economy and Space, 52(1): 66-87.

Platt, E. and Fontanella-Khan, J. (2019) WeWork postpones IPO after chilly response from investors. Financial Times, 16 September. Available at: <https://www.ft.com/content/b869bc42-d8d911e9-8f9b-77216ebe1f17>. Accessed 29 April 2020.

Ritter, J.R. (2011) Equilibrium in the IPO market. [SSRN Scholarly Paper] Rochester, NY: Social Science Research Network. Available at: <http://papers.ssrn.com/abstract=1822542>. Accessed 1 September 2016. 
Sahlman, W.A. (1990) The structure and governance of venture-capital organizations. Journal of Financial Economics, 27(2): 473-521.

Simon, H. (1972) Theories of bounded rationality. In: McGuire, C.B. and Radner, R. (eds.) Decision and Organization. Amsterdam: Elsevier Science Publishing, 161-76.

Singer, D. (2018) Anniversary of Snap IPO to trigger final lockup expiration. Bloomberg, 1 March. Available at: <https://www.bloomberg.com/news/articles/2018-03-01/anniversary-of-snap-ipo-totrigger-final-lockup-expiration>. Accessed 1 June 2018.

Snap Inc. (2017) Snap Inc. S-1 Registration Statement. Washington, DC: US Securities and Exchange Commission. Available at: <https://www.sec.gov/Archives/edgar/data/ 1564408/000119312517029199/d270216ds1.htm>. Accessed 21 May 2018.

Srnicek, N. (2016) Platform Capitalism. Cambridge: Polity Press.

Stross, R. (2000) EBoys: The First Inside Account of Venture Capitalists at Work. New York: Crown Publications.

Thrift, N. (2001) 'It's the romance, not the finance, that makes the business worth pursuing': Disclosing a new market culture. Economy and Society, 30(4): 412-32.

Waters, R. (2017) Uber crafts share sale plan to prop up valuation. Financial Times, 16 August. Available at: <https://www.ft.com/content/51d97262-82da-11e7-94e2-c5b903247afd>. Accessed 04 June 2018.

Williams, J.W. (2020) Recidivists, rough sleepers, and the unemployed as financial assets: Social impact bonds and the creation of new markets in social services. In: Birch, K. and Muniesa, F. (eds.) Assetization: Turning Things into Assets in Technoscientific Capitalism. Cambridge, MA: MIT Press, 287-312.

Yenkey, C. (2010) Selling value in Nairobi's stock exchange. In: Beckert, J. and Aspers, P. (eds.) The Worth of Goods: Valuation and Pricing in the Economy. New York: Oxford University Press, 247-71. Zook, M. (2005) The Geography of the Internet Industry: Venture Capital, Dot-coms, and Local Knowledge. Malden, MA: Blackwell.

Zuckerman, E.W. (1999) The categorical imperative: Securities analysts and the illegitimacy discount. American Journal of Sociology, 104(5): 1398-438. 